\title{
THE EUROPEAN CORN BORER ON LONG ISLAND ${ }^{1}$
}

\author{
By S. M. Dohanian
}

Bureau of Entomology, U. S. Department of Agriculture

The land area of that part of New York State known as Long Island and composed of Kings, Queens, Nassau, and Suffolk counties, is 30 percent greater than that of the State of Rhode Island. Of the 878,720 acres of land on Long Island 126,108 acres were under cultivation in 1929 according to the latest available agricultural census. Long Island is about 120 miles long, its greatest breadth being 20 miles. An irregular range of low hills extends most of the length of the Island a little north of the center; south of this range the surface is comparatively level, while to its north hills and valleys predominate. The average elevation of the land along the north side is about 100 feet, there being only 4 or 5 hills with an altitude greater than 300 feet.

Outside of a considerable residential portion practically all of Nassau County, a large part of the townships adjacent to it on the east, and the entire eastern half of Suffolk County (where the soil permits) are under intensive cultivation. The chief products are potatoes, corn, cauliflower, lima beans, and various truck crops. The 1930 census figures show that 40,350 acres were planted to potatoes, 6,257 acres to field corn, and 4,957 acres to sweet corn.

The first infestation on Long Island by the European corn borer (Pyrausta nubilalis Hübner) was discovered in Kings County (Brooklyn) in August 1923. ${ }^{2}$ The larvæ found

1 "The Long Island Project," conceived by D. J. Caffrey, was started in 1927 by R. A. Vickery. R. E. Kimport continued the work from 1928-1930 under the direct supervision of Mr. Caffrey, in 1931 under B. E. Hodgson, and in 1932 and 1933 under A. M. Vance. Acknowledgement for helpful criticism in the preparation of this paper is due A. M. Vance, and D. W. Jones.

${ }^{2}$ During the period 1923-1928, unsuccessful efforts were made both by State and Federal agricultural authorities to eradicate the corn borer infestation in this and contiguous areas. 
proved to be of the one-generation strain. In 1927 four townships (Southold, Shelter Island, Southampton, and East Hampton) at the extreme eastern end of the Island were found to be infested with the two-generation strain of the borer. The Bureau of Entomology, by establishing a field laboratory on the Island, took immediate advantage of the opportunity thus presented of studying the two strains of this pest simultaneously in the presence of extensive corn acreages and in a situation more or less typical of a large area along the Atlantic seaboard. The principal objective of this project, which was carried on in cooperation with the Bureau of Plant Quarantine, was to ascertain the sources of residual overwintering borer population that would form the nucleus of the reinfestation in the following spring. ${ }^{3}$ Incidentally much information of a varied character was obtained which has led to a better understanding of the insect.

The easterly dispersion of the one-generation strain of the borer from the site of the original colony at the extreme western tip of the Island has been slow indeed. During the decade of its existence there the borer has invaded an average of only 4 miles of new territory each year. This seems a comparatively slow spread when the nature of the terrain, the general direction of the prevailing winds, and the abundance of corn are considered as factors exceptionally favorable for dispersion. Among the probable factors restraining a more rapid spread may be mentioned (1) the efforts at eradication practiced in this area from 1923 to 1928, inclusive, by the Bureau of Entomology in cooperation with the State of New York; (2) the absence of field corn on that end of the Island, which limits hibernating quarters for the borers; (3) the fact that the one-generation borer rarely attacks weeds, which also limits hibernating quarters; and (4) the fact that in this district, where considerable early sweet corn is grown for metropolitan New York markets, many of the cornfields are plowed under as soon as the ears have been harvested (while the stalks are still green and the corn borer larvæ within are in the immature feeding stages) preparatory to the planting of fall crops.

${ }^{3}$ The results of this investigation have been summarized in an unpublished manuscript by R. E. Kimport. 
On the other hand, the westward spread of the two-generation strain of the borer from the eastern end of the Island has been more than twice as rapid. In 1927, Mattituck, on the north fork, and Southampton, on the south fork, formed the western limits of the two-generation infestation, while in the late summer of 1933 evidences of this strain were encountered as far west as Greenvale in Nassau County, a distance of about 60 miles. Consequently, there

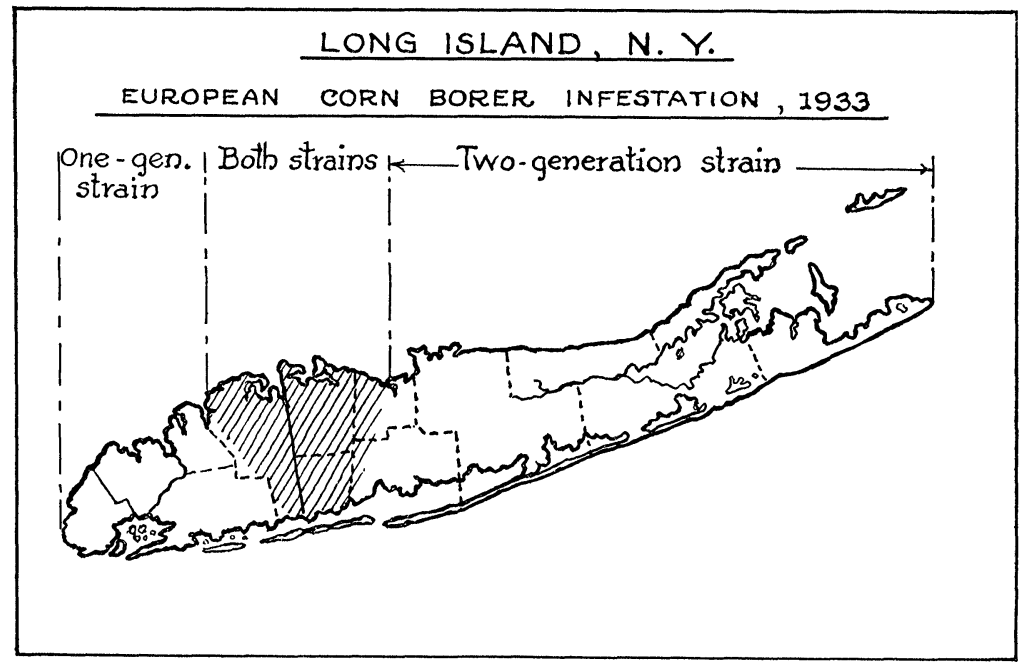

Fig. 1. Map showing distribution of both broods of the European Corn Borer on Long Island

exists (1933) an overlapping of the two strains in an area of approximately 275 square miles a little west of the center of Long Island. In the townships of Oyster Bay in Nassau County and Babylon, Islip, Huntington, and Smithtown in Suffolk County evidences of both the one-generation and the two-generation strains have been found.

Since 1928 annual "infestation surveys" have been made to determine the intensity of European corn borer infestations in corn in both the single-brood and the double-brood districts of Long Island. In the former the surveys were conducted in midsummer, while in the latter they were made 
in the early fall after the second generation larvæ had become established in corn. There appears to have been a slow but steady increase in the borer population of the onegeneration district from 1928 to 1933 . The average number of borers per 100 plants was 1.2 in 1928, 2.4 in 1929, 3.4 in 1930, 13.4 in 1931, 5.5 in 1932, and 8.6 in 1933.

In the two-generation district the average number of borers per 100 plants was 128.5 in $1928,50.9$ in $1929,65.7$ in 1930, 401.9 in 1931, 394.4 in 1932, and 356.5 in 1933. It may be seen that previous to 1931 the infestation in Suffolk County was not heavy. The decided increase in numbers that occurred that year in the eastern half of the county, which has since been maintained, made it the most severely infested district in the entire area occupied by the twogeneration strain of the European corn borer for the years 1931 and 1932. To illustrate the severity of infestation a cornfield may suffer, an actual case in Southold Township, on the north fork, may be cited. In 1931 this field showed a 100 percent plant infestation. The dissection of 10 infested plants, selected in accordance with a uniform method of sampling, gave an average of 57 borers per plant. The borer population of the field was therefore 5,700 borers per 100 plants. Seventy-four borers was the maximum number found in a single plant in this field. Undoubtedly a number of factors are responsible for the continued heavy infestation in the eastern half of Suffolk County. Not the least among these may be the enormous carry-over in potato plants of the first-generation borers, which afterward infest corn. Thousands of acres of both corn and potatoes are interspersed throughout the eastern half of Suffolk County.

The larvæ of the European corn borer have been found infesting 23 kinds of plants on Long Island, among which are vegetables, flowers, and weeds. A systematic survey of the Island would probably enlarge the following list of host plants compiled by R. E. Kimport.

Zea mays L. (corn).

Holcus sorghum L. (Sudan grass).

Echinochloa crusgalli (L.) Beauv. (barnyard grass).

Chaetochloa sp. (foxtail). 
Iridaceae (iris family): Gladiolus hybrids (gladiolus).

Rumex sp. (dock).

Polygonum hydropiper L. (common smartweed).

Rheum rhaponticum L. (rhubarb).

Chenopodium album L. (lamb's-quarters).

Beta vulgaris crassa Alef. (beet).

Spinacia oleracea L. (spinach).

Amaranthus retroflexus L. (pigweed).

Phaseolus vulgaris L. (kidney bean).

Phaseolus lunatus macrocarpus Benth. (lima bean).

Solanum tuberosum L. (potato).

Solanum melongena L. (eggplant).

Lycopersicon esculentum Mill. (tomato).

Cucumis sativus L. (cucumber).

Cucumis melo L. (muskmelon).

Cucurbita pepo L. (pumpkin).)

Ambrosia elatior L. (ragweed).

Dahlia pinnata Cav. (dahlia).

Arctium sp. (burdock).

According to B. E. Hodgson ${ }^{4}$ eight of these plants are "true hosts," serving the dual purpose of food and hibernation. To date corn is the only plant known to suffer real commercial damage. Two other major crops of the area, however, although their yield is probably not seriously lowered by the European corn borer, are considered extremely important hosts. The first of these is the potato. This plant is attacked rather severely at times by the first-generation borer. For example, in 1933, in Suffolk County, potato plants harbored 51 first-generation borers per square rod to 99 borers in each square rod of corn. The liking which the European corn borer appears to have for the potato plant is of considerable significance in view of the fact that this plant serves as a convenient and very important carryover host, thus furnishing moths of the first generation to attack corn and some of the late vegetable crops. Where corn and potatoes are planted in close proximity, danger of serious commercial damage to corn, and possibly also to potatoes, is greatly enhanced.

${ }^{4}$ Hodgson, B. E. The host plants of the European corn borer in New England. U. S. Dept. Agr., Tech. Bull. 77, 63 pp., illus. 1928. 
The other important host plant is the lima bean. Although there is but little loss in yield from the attacks of the European corn borer on lima beans, this plant becomes a potential means of spread for the insect into noninfested areas, when its pods are transported into such territory.

The development of a severe infestaton in the two-generation district on the eastern tip of the Island, and its practical isolation from neighboring infestations, presented an excellent opportunity to demonstrate the extent and efficacy of control by parasites. Accordingly, during the summer of 1933 a total of 67,435 imported parasites of the European corn borer were liberated at carefully selected points in the eastern half of Suffolk County. In these liberations were represented 13 European and 3 oriental species, as shown in the following list:

\section{Species}

Apanteles thompsoni Lyle

Campoplex multicinctus (Grav.)

Number of

Campoplex pyraustae Smith Individuals

Ceromasia lepida Meig. (oriental)

Chelonus annulipes Wesm.

Cremastus flavoorbitalis (Cam.) (oriental)

126

Eulimneria alkae Ell. \& Sacht.

Eulophus viridulus Thoms.

Inareolata punctoria (Roman)

Lydella stabulans var. grisescens R.D.

19,524

Macrocentrus gifuensis Ashm.

Microgaster tibialis Nees

Phaeogenes nigridens Wesm.

Phorocera erecta Coq. (oriental)

Zenillia mitis Meig.

Zenillia roseanæ B. \& B.

\section{Total liberated}

67,435

Judged by their past ability to adapt and acclimatize themselves, and by the effective work they have done since their introduction into both the New England and the North Central State areas, it seems very probable that the 
two parasites Inareolata punctoria and Lydella grisescens will be the first to become established and to prove beneficial on Long Island. In addition to the numbers of these two species liberated in 1933, as shown above, 1,229 individuals of $I$. punctoria and 5,916 of L. grisescens were colonized in the township of Southold, in the north fork, during the summer of 1932. Except for these two species, no parasites of the European corn borer, however, had ever been liberated on Long Island previous to 1933. A parasite census here four or five years hence should supply interesting results and useful information.

When the European corn borer invaded Long Island it seemed to have found ideal conditions in which to live and to thrive. Favorable weather conditions combined with the abundance of corn on the Island furnished an environment strongly in its favor. The absence of its natural parasites and diseases also aided its rapid increase. Paradoxical though it may seem, the farmers themselves unwittingly assisted its increase by failing to destroy the materials in which the borers hibernate. (New York State has not enacted the "compulsory corn borer clean-up" law in force in some of the New England States). The history of the European corn borer on Long Island has been such as to make the invasion by this insect an important economic problem not only for Long Island but also for other areas along the Atlantic seaboard where conditions are similar, and some of these are already infested. 

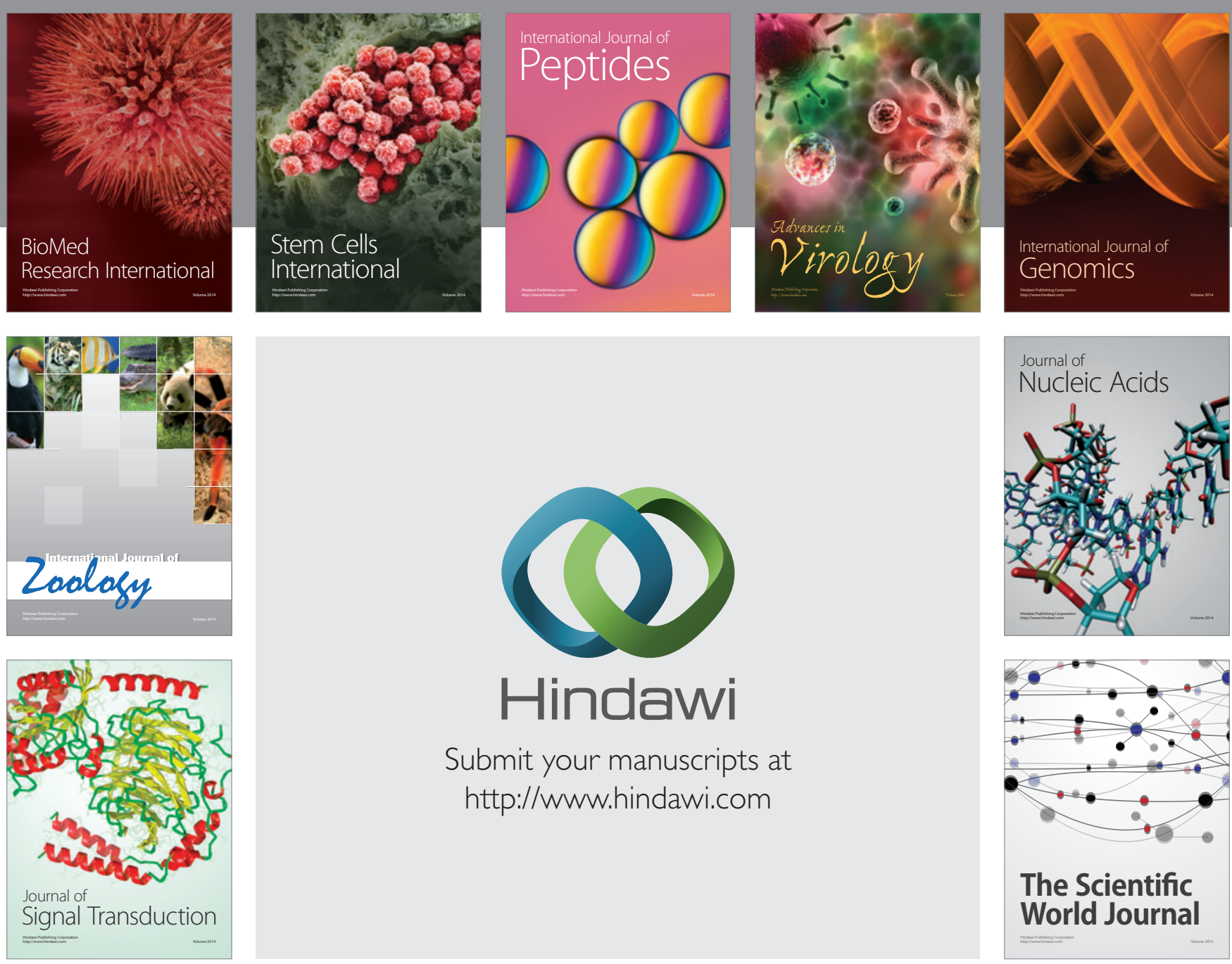

Submit your manuscripts at

http://www.hindawi.com
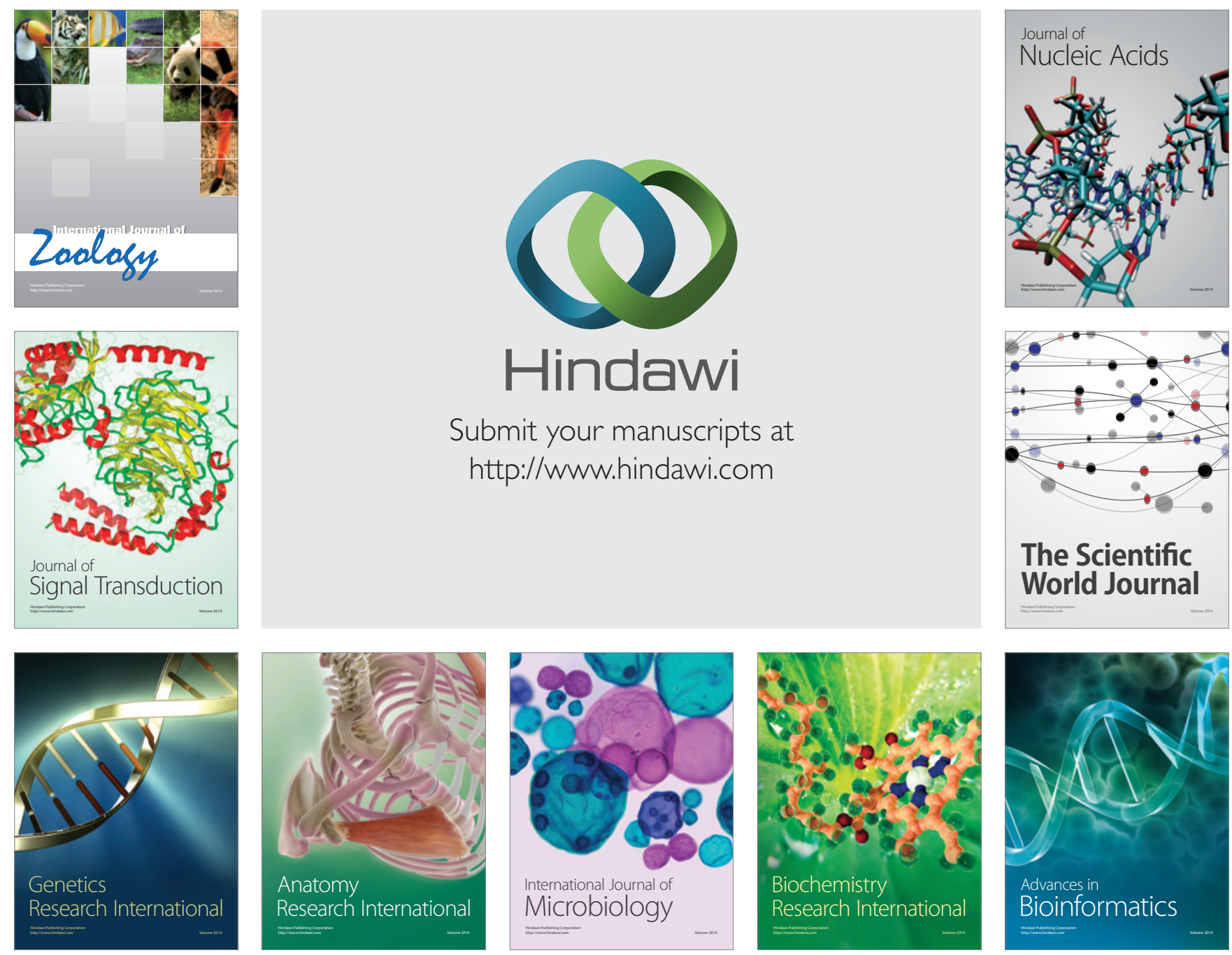

The Scientific World Journal
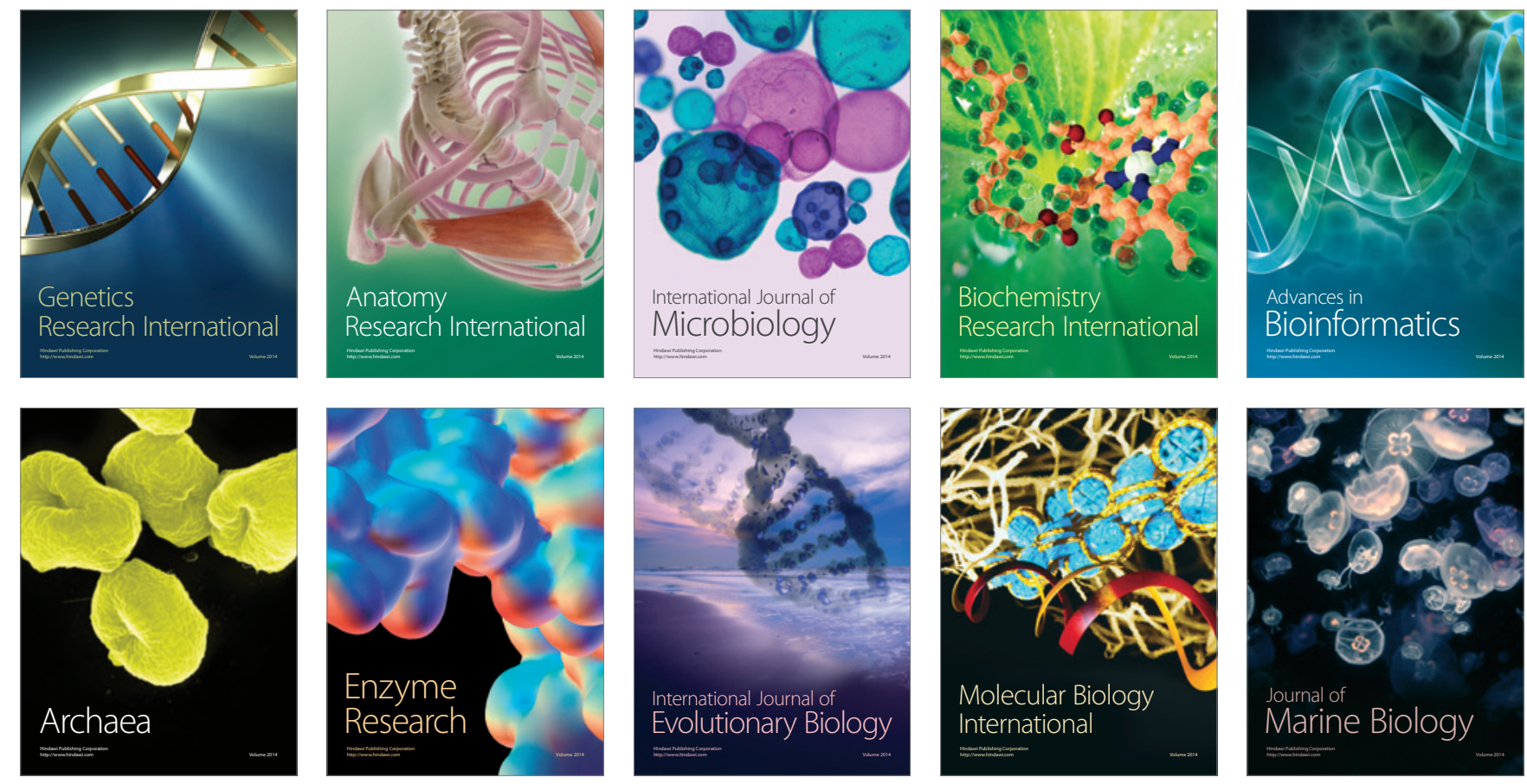